Bu makaleye atıfta bulunmak için/To cite this article:

ALİAĞAOĞLU, A. ÇETINKAYA, S. (2021). Türkiye'de Değișen Belediye Logoları: Küreselleşme ve Başka

Nedenler. Atatürk Üniversitesi Sosyal Bilimler Enstitüsü Dergisi, 25(Özel Sayı), 44-64.

\title{
Türkiye'de Değişen Belediye Logoları: Küreselleşme ve Başka Nedenler
}

\author{
Alpaslan ALIA $\breve{G} A O \breve{G} L U^{(*)}$ \\ Sema ÇETINKAYA ${ }^{(* *)}$
}

Öz: Kentler çok nüfuslu, çok işlevli, tarımsal işgücünün önemli olmadı̆̆ı, farklı yaşam biçimlerine sahip insan yapımı merkezi yerlerdir. Kentler küreselleşme sürecinin sahnelendiği mekânlardır. Bu süreçte yaşanan değişim ve dönüşümler kentlerde açık bir şekilde gözlenebilmektedir. Bu değişimlerin toplamı veya bir kısmı logolarla anlatılabilmektedir. Logolar farkl bilimler tarafindan incelenmektedir. Pazarlama, iletişim, resim, sanat tarihi, turizm ve coğrafya logoları farklı şekilde ele almaktadır. Logolar kent kimliğinin özü veya özetidir. Onlar farkındalık oluşturan ve özgünlüğü ifade eden değişen varlıklardır. Bu çalışmada Türkiye'de bazı belediye logolarındaki değişim ele alınmıştır. Veriler google' den temin edilmiş, yorumlayıcı anlamaya yönelik coğrafik içerik analizi yapılmıştır. Logolardaki değişimin temel nedeni daha çok küreselleşmedir. Küreselleşme geçmişe dönmeyi veya nostalji duygusunu, tarihi değerlere sahip çıkmayl, rekabet etmeyi, markalaşmayl teşvik etmektedir. Siyasi nedenler de logoları etkilemektedir. Bu açıdan logolar siyasi erkin ideolojik öncelikleri arasindadır. Kuşkusuz logolardaki değişim nedenleri her zaman tek nedene bağlanamaz. Nostalji güdüsü, kişisel nedenler, modanın değişimi, nüfus artışı ve şehirlerin büyümesi başka nedenler olarak ortaya çıkmaktadır.

Anahtar Kelimeler: Türkiye, logo, değişim, küreselleşme, politik görüş.

\section{Changing Municipal Logos in Turkey: Globalization and Other Reasons}

Abstract: With different lifestyles, cities are multi-populated, multi-functional, man-made central places where agricultural workforce is not important. Also, cities are places where the globalization process is staged. The changes and transformations experienced in this process can be clearly observed in cities. The sum or some of changes can be explained by logos. Logos are studied by different sciences. Marketing, communication, painting, art history, tourism and geography treat logos differently. Logos are the essence or epitome of urban identity. There are changing beings that create awareness and express authenticity. In this study, changes in some municipal logos in Turkey were discussed. The data was sourced from google, and geographic content analysis was conducted for interpretive understanding. The main reason for the change in logos is more globalization. Globalization encourages a return to the past or a sense of nostalgia, ownership of historical values, competition, and branding. Political reasons also influence logos. In this respect, logos are among the ideological priorities of political power. Of course, the logos cannot always be linked to one reason. The motive fornostalgia, personal reasons, the change of fashion, population growth and the growth of cities appear as other reasons.

Keywords: Turkey, logo, change, globalization, political view.

*)Prof. Dr. Balıkesir Üniversitesi Fen-Edebiyat Fakültesi Coğrafya Bölümü, (e-posta: alpaslan38ster@gmail.com), (D) ORCID ID. https://orcid.org/0000-0002-6198-3878

$\left.{ }^{* *}\right)$ Arş. Gör. Balıkesir Üniversitesi Sosyal Bilimler Enstitüsü Coğrafya Anabilim Dalı, (e-posta: semacetinkaya57@gmail.com), (D) ORCID ID. https://orcid.org/0000-0002-6198-3878

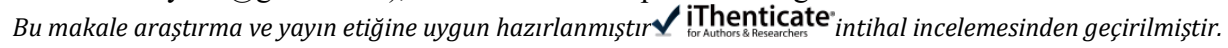


Makale Geliş Tarihi: 05.02.2021

Makale Kabul Tarihi: 23.09.2021

DOI:10.53487/ataunisosbil.875426

\section{Giriş}

Kentler doğa, tarih ve kültürün cisimleş halidir. Kentlerde tüm bir geçmişin, fiziksel çevrenin, yapılı çevrenin ve farklı yaşam tarzlarının yansıması bulunur (Takış, 2013-14). Kentlerin adları, kimlikleri, ruhları, kokuları ve sesleri yanında logoları da vardır. Logo kavramı Latince Logostan gelmektedir. Konuşma ve mantık anlamına sahiptir. Logolar kendisini görenlere seslenir, ancak kullanımı mantıklı olmalıdır (Çamdereli, 2004). Logolar kentleri diğer kentlerden ayrı kılan eşsiz sembollerle doludur. Çok nüfuslu, çok işlevli, tarımsal işgücünün önemli olmadığ 1 , farklı yaşam tarzlarına sahip, insan yapımı ve merkezi yerleşmeler olan kentler" beton kitap" (Hugo, 1996: 64)olarak da tarif edilmektedir. Kentler değişimin sürekli olduğu yerleşmelerdir. $\mathrm{Bu}$ değişim bugün küresel ölçekte yaşanmaktadır. Bu duruma bağlı olarak beton kitabın değişik zamanlarda farklı baskıları yapılmaktadır. Bu kitabın kapağında logolar bulunmaktadır. Logolar da her baskıda değişime uğrar. Onlar kentleri, kentlerin sahip oldukları sosyo-kültürel, sosyo-ekonomik özellikler yanında yapılı ve doğal çevreyi de anlatırlar. Logolar insanları mekân ve yerle ilgili duygu ve düşüncelerini ortaya koyarlar. Değişen koşullara uyum sağlama çabasında kentler gibi logolar ve bunlarda kullanılan semboller de zamanla yeniden üretilmektedir. Bu çalışma belediye logolarında yaşanan değişimi ve bu değişimin nedenlerini ortaya koymaktadır. Değişimin arka planında çeşitli nedenler vardır. Küreselleşmeyle ortaya çıkan kaos ortamı, kentler arasında yaşanan rekabet, ekonomik temeldeki değişim ve siyasi nedenler bunlar arasındadır.

Coğrafya insan eylemiyle değişen yeryüzünün yani mekânın incelenmesidir. Coğrafya bilimi de logoları ele almaktadır. Çünkü onların üzerindeki semboller doğal ve beşeri coğrafya özelliklerinden esinlenmektedir. Coğrafya bilimi iki başlık altında ele alınmaktadır. Bunlar fiziki ve beşeri coğrafyadır. Fiziki coğrafya yeryüzünün fiziki kısımlarıyla ilgilidir. Beşeri coğrafya insanı, özelliklerini, faaliyetlerini çevresiyle ilişki içinde ve meydana getirdikleri mekânsal örgütleme biçimiyle ele alır. Bu nedenle fiziki coğrafyaya kıyasla daha geniş inceleme alanı vardır (Tümertekin ve Özgüç, 2017). Hastalıklar, suçlar, spor, müzik, duvar yazıları, mekâna bağlı sembolizm beşeri coğrafyanın bazı inceleme konularıdır. Bu yönüyle sembol veya sembollerden oluşan logolar coğrafi açıdan ele alınabilir. Ancak bu tasarım ilkeleri şeklinde değil coğrafi içerik analiziyle ilişkilidir. Bu konuda ülkemizde farklı yerleşme veya il dâhilindeki ilçelerin belediye logolarının coğrafi içerik analizi yapılmıştır. Bu çalışmalara göre logolarda bazen beşeri çevre bazen de fiziki çevre elamanları sıkça kullanılmıştır. Başka bilim dalları da logolarla ilgilidir. Onlarda Türkiye' deki valiliklerin veya il dâhilinde kurumlar ait logoları gerek tasarım elemanları, ilkeleri, içerik açısından anlambilimsel olarak değerlendirmişlerdir. Turizm ve pazarlama da logolarla ilgilidir. Şehirlerin imajı ve markalaşması sürecinde logolar kullanılmaktadır. Logolardaki değişim konusunda çalışma, bir çalışma dışında (Şenol, 2020) yapılmış değildir. Bu çalışmada Türkiye'de belediye logolarındaki değişimin arka planı ele alınmaktadır. Çalışma Türkiye'de 
değişen bütün belediye logolarının tam bir listesini vermek amacında değildir. Ancak iki sorunun cevabını bulmaya yöneliktir. Bunalar aşağıdaki gibidir:

1. Politik görüşte meydana gelen değişim belediye logoları nasıl etkilemiştir?

2. Küreselleşme süreci belediye logolarının yeniden tasarımını nasıl etkilemiştir?

Çalışma giriş bölümü dışında üç başlık altında ele alınmaktadır. Yöntem kısmında çalışmanın yöntemi verilmektedir. İlgili yayınlar ikinci alt başlıktır. Bu bölümde, yabancı ve yerli kaynakların taraması yapılmaktadır. Kavramsal çerçeve başka bir bölümde ele alınmaktadır. Bu bölüm üç alt başlıktan oluşmakta ve çalışmanın arka planını vermektedir. "Türkiye'de değişen belediye logolar" başlığı başka bir bölümü nitelemektedir. Logolardaki değişim, nedenleri ve coğrafi içerik analizi bu bölümde yapılmaktadır. Makale sonuç bölümüyle tamamlanmaktadır. Bu bölümde problem tekrar ifade edilmekte, mevcut literatürle karşılaştırma yapılmakta ve genellemelere gidilmektedir.

\section{A. Yöntem}

Türkiye'de belediye logolarındaki değişimi esas alan bu çalışmada hümanistik yaklaşım kullanılmışıır. Hümanistik yaklaşım yorumlayıcı anlamaya yönelik yaklaşımdır. Hümanistik yaklaşıma göre bilimsel coğrafya insan deneyiminin tamamını açıllayamaz. Bunlar bireyler ve gruplar ile yer ve coğrafî görünümler arasında derin, öznel ve çok karmaşık olan ilişkileri anlamaya çalışıllar (Uğur ve Aliağaoğlu, 2019). Çalışmada kullanılan veriler internet ortamından elde edilmiştir. Google arama motoruna, "logosu değişen belediye yerleşmeleri" yazılarak, logosu değişmiş, yakın zamanlı değişen ve değişme ihtimali olan belediyeler belirlenmiştir. Genel olarak eski ve yeni logolar tespit edilmiştir. Değişen logoların halihazırda kullanılması dikkate alınmamış, logolar değişim nedenlerine göre coğrafi içerik analizi yapılmış, eski ve yeni logolar tahlil edilmiştir. Değişim nedeni aynı olan logolardan rastgele bir örnek verilmiş̧tir. Değişim nedenlerinin tespiti logoların incelenmesi sonrasında öznel olarak yapılmıştır. Bu durum çalışmanın sınılılığı olarak kabul edilebilir. Doküman analizi kullanılan başka bir yöntemdir. Başka bir anlatımla literatür taraması, konuyla ilgili yayımlanmış çalışmaların; gözden geçirme, değerlendirme ve sentezleme yöntemidir(Demirci, 2014).

\section{B. İlgili Yayınlar}

Logolar konusunda farklı çalışmalar yapılmıştır. Bunlardan bir kısmı bir il dâhilinde bulunan belediye yerleşmelerindeki logoların coğrafi içerik analizi şeklindedir. Bu tür çalışmalar daha çok coğrafyacılar tarafından yapılmıştır. Sinop (Şenol ve Saraçoğlu, 2013), Kocaeli (Uzun ve Özcan,2014), Balıkesir (Aliağaoğlu ve Çildam, 2015), Erzurum (Aliağaoğlu ve Uğur, 2018), Çankırı (Türkan, 2018), Samsun (Yıldırım, 2018), Giresun (Şenol, 2020), bu açıdan ele alınmış başlıca illerdir. Şenol (2020) il genelinde logosu değişen ilçeleri de ele almakta ve logo tasarımcılarından alınan bilgiler analiz edilmektedir. Aynı çalışma bu konuda yapılan bütün çalı̧̧maları ortaya koyması bakımından da önemlidir. Aliağaoğlu (2007), konuyu Türkiye ölçeğinde ele almaktadır. $\mathrm{Bu}$ çalı̧̧mada il merkezi olan kentler dikkate alınmaktadır. Sinop'ta genel olarak doğal çevre unsurları ön plandayken, kıyı yerleşmelerinde logolarda daha çok sembol 
kullanıldığı tespit edilmiştir. İç kesim logolarında beşeri çevre ön planda bulunmakta, kıyılarda doğal semboller çoklukla kullanılmaktadır. Kocaeli ili belediye logolarında sanayi faaliyetleri daha çok sembolize edilmektedir. Kocaeli'nin tersine Balıkesir ilinde sanayi sembolü az kullanılmıştır. Bitki ve tarımsal ürün kullanılan en önemli sembollerdir. Deniz figürü beş ilçede kullanılmakta, coğrafi konum ve turizm faaliyetini ifade etmektedir. Güneş figürü de aynı anlamda kullanılmaktadır. Kullanılan bir başka sembol çevrenin önemli bir tarımsal ürünü olan zeytin, zeytin dalı ve zeytin tanesidir. Bu konuda ortaya çıkan bir farklılık da Çanakkale savaşının önemli siması olan Koca Seyit'in Havran Belediyesinde sembol olarak kullanılmasıdır. Samsun'da fiziki ve beşeri çevreyi ifade eden sembollerin birbirine yakın olarak kullanıldığı ifade edilmektedir. Logolarda çok sayıda sembol kullanılmıştır. Çankırı'da az nüfuslu belediyelerde fiziki çevre elemanlarının ön plana çıktığı ifade edilmektedir. Erzurum'da beşeri çevreyi anlatan semboller daha fazladır. Ancak fiziki çevre elamanları da kullanılmıştır. Semboller gerçek anlamlarıyla kullanılmıştır. Giresun'da bazı ilçe logolarında değişim söz konusudur. Bunlar, Piraziz, Eynesil, Çanakçı, Şebinkarahisar, Alucra ve Çamoluk belediyeleridir. Beşeri çevre sembolleri ile fiziki çevre sembolleri bazı ilçe belediyelerinde kullanılmıştır. Logoların halk tarafından bilinmemesi söz konusudur. Ülke genelinde kullanılan sembollerde çeşitlilik söz konusudur. Bu özellik ülke coğrafyasından ayrı tutulamaz. Çünkü Türkiye bal peteğine benzer bölümlerden oluşmaktadır. Aynı özellik tarımsal ürünlerin çokluğu ile de ilgilidir. Ayrıca ülke uzun zaman tarım ekonomisinin etkisinde kalmıştır. Sanayi sembolleri az kullanılan sembollerdir. Kullanılan yerleşme sayısı azdır. $\mathrm{Bu}$ da yerleşmelerin gelişmişliğini göstermektedir. Oysa tüm ülke için aynı şeyi ifade etmek güçtür.

Logolar coğrafyacı olmayanlar tarafından da çalışılmıştır. Karaalan (1998), Türkiye İl Amblemleri adlı tez çalışmasında, Belediye logolarını il amblemi olarak ifade etmiş̧ir. $\mathrm{Bu}$ da idari coğrafyanın zayıflı̆̆ını göstermektedir. Sonuç itibarıyla, Türkiye'nin doğal ve beşeri coğrafi özelliklerinin zenginliğine rağmen bunlar logolarda yansitılmamıştır. Logolarda grafiksel özellikler dikkate alınmamıştır. Bu durum renk çokluğu, biçim eksikliği, kompozisyon düzensizlikleri, resimsel ifadeler ve ayrıntının çokluğu ile ifade edilmektedir. Yine logoların profesyonel olmayanlar tarafindan çizildiği ifade edilmektedir. Konya (Büyükçanga, 2003) ve Konya ilçeleri (Büyükçanga, 2004) ele alınan başka bir çalışmadır. Demir (2013) Mersin'de bulunan bütün kurum ve kuruluşlarının logolarını grafik tasarım bakımından ele almaktadır. Çalışmaya göre, ilde yer alan logolar daha çok Mersin Büyükşehir Belediyesi logosundan esinlenmiştir. Logoların seçilmesi işveren ve kurumlar tarafından keyfi olarak yapılmaktadır. Görgülü (2019), Antalya kent logosunu göstergebilimsel olarak ele almaktadır. Bilirdönmez ve Şahin (2019), Doğu Karadeniz Bölümünde yer alan 6 il merkezinin belediye logolarını tasarım ilkeleri açısından incelemişlerdir. Artvin Belediyesi logosunun iyi stilize edilmediği sonucuna varılmıştır. Giresun Belediyesi logosunun yeni olmasına rağmen değişikliğe ihtiyacı olduğu, diğer belediyelerde grafik tasarım açısından sorun olmadığı ifade edilmektedir. Kavuran ve Çetinkaya (Tarihsiz), Elazı ğ ili ve ilçe belediye logolarını grafik tasarım açısından ele almışlardır. Sonuçta görülmektedir ki, logolar il dâhilinde bulunan tarihi, kültürel ve turistik değerleri yansıtmaktadır. Fakat grafik tasarım açısından sorunlar vardır. Bir kere logolarda üç renkten fazlası kullanılmamalı ve 
fotoğraf logoda yer almamalıdır. Son olarak Demirkol (2019), Türkiye'de valilik logolarını, tasarım elemanları, tasarım ilkeleri ve içerikleri açısından incelemiş ve aşağıda ifade edilen sonuçlara ulaşmıştır: Logolar amatörce yapılmış ve yenilenmemiştir. $\mathrm{Bu}$ durum çağdaşlık ilkesine ters düşmektedir. Logolarda bütünlük ve uyum yoktur. Renk sayısı üçten fazla olup, sadelik ilkesine uyulmamıştır. Logolarda yazı olmaması nedeniyle temsil özelliği yoktur. Sadece tarım ve ticari ürünlerin kullanılması dolayısıyla logoların algılanabilirlik ve kalıcılık özelliğinin olmadığı ifade edilmektedir. Valilik binasının logolarda sıkça kullanılması da olumlu bir durum değildir.

Küreselleşme sonucu kentler arasında rekabet de yaşanmaktadır. Bu rekabet farklı çalışmalarla ortaya konulmuştur. Çamlıdere, Varlı, Varlı ve Gürer, (2006), kentlerin marka değerini oluşturma bakımından logoların önemi üzerinde durmaktadırlar. Büyükşsehir belediyesi logoları ile Kocaeli ili logolarını ele almaktadırlar. Logolardaki semboller kentlerin tarihi, ekonomik, doğal ve kültürel değerlerinden etkilenmiştir. Kızıltaş (2017), ülke ve uluslararası şehir logolarını markalaşma açısından ele almaktadır. Tarihi geçmişi eski olan ülke ve şehirler, sahip oldukları kültürel miraslarını vurgularken, tarihi birikimi zayıf olanlar günümüz tasarım anlayışına sahip modern logoları tercih etmektedirler. Logoların kentlerin kimliğini ifade etmesi dolayısıyla, kentlerin markalaşması ve pazarlanması konusunda çok sayıda çalışma yapılmıştır. Bu konuda yapılan güncel çalışmalar Şenol (2020) tarafından sıralanmaktadır: Braun, 2008; Giritlioğlu ve Avcıkurt, 2010; Zeren, 2011; Vermeer, Kavaratzis ve Hatch, 2013; Fettahlığlu, Yıldız ve Göksu, 2017; Kurtoğlu, 2017; Özsöz, 2018; Görgülü, 2019. 2011.Wahyurini'ye göre (2012), Melbourne şehir logosunu geliştirmek, bunu şehir sakinleri ve diğer paydaşların katkılarıyla sağlamak, şehrin uluslararası tanınırlığını artıracağı gibi, güçlü ve etkili bir logonun ortaya çıkışını mümkün kılacaktır. Lee vd. (2012), ABD'de turizmde ülke logolarının rolünü lisans öğrencileri üzerinden araştırmışlardır. Sonuçta görülmüştür ki ülke logolarının dizaynı turizmi olumlu yönde teşvik etme kabiliyetine sahiptir. Köşker vd.,(2019) bu konuda çalışma yapan başka bilim insanlarıdır. Kaypak (2013) daha çok markalaşma üzerine alanyazınsal çalışma yapmıştır. Yenipınar ve Yıldırım, (2016) destinasyonun markalaşması bakımından Muğla ilinde bulunan kurum ve kuruluşların logolarını ele almaktadırlar. Logoların olumlu ve olumsuz yönleri sekiz madde halinde sıralanmaktadır. Kısaca logolardaki simgeler anlaşılır değildir. Renkler çok serttir. Bazı simgelerin abartılı, bazılarının ise silik olduğu görülmektedir. Tarihi ve mitolojik veriler dikkate alınmamıştır. Simgeler karmaşıktır. Yerel kurum ve kuruluşlar öz değerlerinin farkında olmakla beraber, logolar amatörler tarafından yapılmıştır. Muğla Büyükşehir Belediyesi logosunda öz değerlere yer verilmemiştir. Üniversite, Bodrum, Fethiye ve Datça belediyeleri öz değerleri yer vermek bakımından diğer kurumlardan başarılıdırlar. Çeliker ve Tokoğlu, (2017), marka kent oluşumunda grafik tasarımının rolünü Gaziantep kentinde ele almaktadırlar. Markalaşmada grafik tasarımının önemi üzerinde durulmakta ve bunun için grafik tasarım ekibinin iyi seçilmesi gerektiği vurgulanmaktadır. Köşker vd. (2019), Türkiye'de turizm talebinin en yüksek olduğu 10 yerleşmenin logolarını marka kimliği oluşturma bakımından ele almaktadır. Bu kentlerin, kent, belediye ve valilik logolarında aynı sembol ve renklerin kullanıldığı ancak logolarda kompozisyon bütünlüğünün sağlanmadı̆̆ 
Konu küreselleşmeye bağlı olarak ortaya çıkan kentsel ekonominin değişimini ortaya koymak için de çalışılmıştır. Bu konu daha çok yabancılar tarafından işlenmiş̧ir. Sanayinin başlangıç ülkelerinde sanayinin önemini yitirmesiyle, küresel ekonomiyle bağlantı kurmak maksadıyla şehirler logolarını değiştirmiş ve daha çok spor, turizm ve kültürel elemanlara vurgu yapılmıştır. Short vd. (1993), sanayi öncesi ekonomiden sanayi sonrası ekonomiye geçiş sürecinde Syracuse şehri imajında ve dolayısıyla logosundaki değişimi ele almaktadır. Richard ve Wilson (2004), Roterdam şehrini, Smith (2005) üç Avrupa şehrini (Birmingham, Manchester, Sheffield) aynı bakış açısıyla ele almaktadırlar.

\section{Kavramsal Çerçeve}

\section{A. Küreselleşme}

Küreselleşme yalın bir kavram değildir, çok karmaşık bir olgudur. Buna bağlı olarak çok sayıda tanımı yapılabilir. Coğrafi açıdan en uygun tanım "dünyanın tek mekân olarak algılanmasıdır". Ya da Harvey (1996) tarafindan ifade edilen "zaman mekân sıkışmasıdır". Ya da "zamanın mekânı fethetmesidir" (Aslanoğlu, 1998). Tanımları küreselleşmenin farklı yönlerine göre uzatmak mümkündür. Küreselleşme yeni bir süreç değildir. Küreselleşme başlangıçta farklı zamanlarda ekonomik nedenlerle çeşitli dalgalar (iki veya üç dalga) halinde ortaya çıkmıştır. Oysa tarihi bakış açısııla küreselleşmenin yaşanmadığ dönem yoktur. Ancak herkesin hemfikir olduğu bir durum var ki o da "1980'den beri yeni bir dünyada yaşıyoruz" (Keyder, 1993: 100). Küreselleşme farklı nedenlerle ortaya çıkmıştır.

Sosyalizmin çöküşü bir nedendi. Çünkü bu durum kapitalizme olan güveni artırmıştır. Ulaşım, iletişim ve haberleşmede zaman ve maliyet açısından yaşanan olumlu değişimler başka bir nedendir. Gelişmiş ülkelerde üretimin doyum noktasına ulaşması dolayısıyla azalan verimlilik, üretim hacminin artış göstermesi, devletlerin ticaretin önündeki engelleri kaldırması konusunda olumlu katkıları, uluslararası örgütlerin (IMF, DTÖ, Dünya Bankası gibi) rolünün artması küreselleşmenin başka nedenleri olarak siralanabilir (Uğur ve Aliağaoğlu, 2018).

Küreselleşme sürecinin olumlu ve olumsuz yönleri vardır. Başka bir anlatımla, "Küreselleşmenin fotoğrafi bulanıktır. Bu fotoğrafa bakıldığında hem aydınlık hem de karanlık noktalar görmek mümkündür" (Özyurt, 2005: 130). Bütün bu noktaların detaylı analizini burada yapmak mümkün değildir. Ancak bunlardan bazıları çalışma açısından önemlidir.

Küreselleşme, ekonomik sosyal ve politik olarak yaşanan çok boyutlu bir süreçtir. $\mathrm{Bu}$ sürecin olumlu ve olumsuz çok sayıda sonuçları vardır. Genel olarak bakıldığında, dünya küçülmüş, zaman kısalmış ve sınırlar ortadan kalkmıştır. Medya küreselleşmiş, bilgisayar, internet ve cep telefonu kullanımı yaygın hale gelmiş, www'in (Dünya çapında ağın) yaygınlaşmasıyla birlikte, anında iletişim ve engelsiz bilgi aktarım mümkün olmuştur. Planlanmış, tasarlamış mekân yanında insanlar üçüncü bir mekân olan sibernetik (bilgisayar kontrollü)mekânda yaşar hale gelmişlerdir (Bauman, 2012). $\mathrm{Bu}$ çerçevede kurumların, yerleşmelerin veya firmaların logo kullanımı yaygınlaşmışır. Sınırsız televizyon ve küresel taşıyıcılar küresel köyün önemli elemanları olmuşlardır. 
Küresel televizyon kendi cemaatini oluşturmuş, kamu yararını arka plana atarak ve seyirci (reyting) peşinde koşmaktadır (Tomlinson, 2013). Küreselleşme olgusu yerelin öneminin ve ağırlığının artmasına neden olmuştur. Yerelleşme sorunu gündeme gelmiş, yerele dair birçok özellik kaybolmaya başlamıştır. Bu duruma tepki olarak yerel tarihi, kültürel değerlerin korunması önem kazanmıştır. Küreselleşme mali, sağlık, iş ve kişisel güvensizlik ortaya çıkarmış, bu nedenle gündelik hayat belirsizleşmiştir (Tümertekin ve Özgüç, 2017). Zaten Robertson'a göre (Robertson, 1999), küreselleşme çeşitli dönemleri kapsamaktadır. 1960-1990 arası dönem belirsizlik dönemidir. "Küreselleşme, KennethJowitt'in kitabının başlı̆̆ı olan 'yeni dünya düzensizliğinin' başka bir adı" olmuştur (Akt: Bauman, 2012: 62-64). Sonuç itibarıla, küreselleşmenin belirsizlikleri insanları kendi kültür ve tarihine yakınlaştırmıştır. Ancak küreselleşmenin paradoks içeren yönlerinden biri de farklılık ve yerel kimliklerin çeşitliliğinin ortaya çıkmasıdır (Aslanoğlu, 1998).

Ekonomik yapıdaki değişim ise geleneksel sanayinin önemini yitirmesi, yüksek teknoloji sanayileri ve hizmetlerin ön plana çıkmasıdır. Yine neo-liberal söylemler yükselişe geçmiş, devletler ekonomiden uzaklaşmış, yetkiler özel sektör ve yabancı sermayeye devredilmiştir. Böylece özel sektörün güçlenmesi yerine, uluslararası sermeyenin kontrolü ele geçirmiştir. Küresel sermaye, mal, hizmet ve bilgi akışları genelde kentler arasında geçmektedir (Kiper, 2006). Böylece ulus devletlerin yerini yarışan kentler almıştır. Yarışma gücünü artırmanın yollarından biri değer pazarlaması diğeri ise altyapı pazarlamasıdır. Değer pazarlaması kentin sahip olduğu sosyal, kültürel, tarihsel ve doğal verilerinden oluşur. Değer pazarlaması daha çok turizm ve spor vasıtasıyla gerçekleşir. Altyapı pazarlaması, kentin küresel sermayeye sağladığı imkânları anlatır. İletişim, bilgi işlem alt yapısı bunlar arasındadır (Ocak, 1996). Sonuçta pazarlamanın özellikle değer pazarlamasının ön koşullarından biri de iyi bir logoya sahip olmaktır.

\section{B. Hümanistik Yaklaşım}

Hümanistik yaklaşım kendi içinde farklı yaklaşımları kapsayan genel bir yaklaşımdır. Bu bakış açısı fenomenoloji, varoluş̧uluk, pragmatizm, idealizm gibi felsefi akımlardan beslenmektedir. Tüm bilginin deneyim dünyasından çıktı̆ıııı savunan fenomenolojik paradigma yaygın olarak kullanılmaktadır. Bu yaklaşım 1960 yıllarının sonu 1970 yıllarının başında coğrafya ile tanışmıştır (Kaya, 2014).

Geçmişi eski olmakla birlikte, kavram ilk kez Tuan (1976) tarafindan kullanılmıştır. İnsan, duygu ve davranışlarıyla birlikte karmaşık bir varlıktır. İnsan davranışlarındaki derin anlamlar ortaya çıkarılmalıdır. Bunlar bireyler ve gruplar ile yer ve coğrafî görünümler arasında derin, öznel ve çok karmaşık olan ilişkileri anlamaya çalışıllar. Başka bir anlatımla bu yaklaşımda insan ve çevresi arasındaki ilişki insan merkezli olarak yorumlayıcı anlamayla çözümlenmektedir. Yaklaşımda insan bilinci, ajan olarak insan ve insan yaratıcılığı ön plandadır. Hümanistik coğrafya, insanların doğayla olan ilişkisini, coğrafi davranışlarını, mekân ve yerle ilgili duygu ve fikirlerini inceleyerek, insan dünyasını anlamaya çalışır (Tuan, 1976). Yerlerin tekliği ön plandadır. Yani coğrafik olaylar idiografik olarak ele alınır. Yer, mekân ve yersizlik konuları yaklaşımın en çok üzerinde durduğu konulardandır. Veya hümanistik coğrafyada beş farklı konu ele 
alınır. "Bunları, coğrafi bilgi veya kişisel coğrafyalar, yerin rolü ve yer kimliklerinin oluşturulması, kalabalıklık ve gizlilik, geçim kaynaklarını belirlemede coğrafi faktörlerin rolü ve son olarak dinin etkisi şeklinde sıralamak mümkündür (Tuan, 1976: 267). Bu çalışmada insanların yer ve mekânla ilgili duygu ve düşünceleri logolar bağlamında ele alınmaktadır.

\section{Logolar}

İnsanlar duygu ve düşüncelerini beden dili, söz, müzik, resim ve yazı ile farklı şekillerde ortaya koymuşlardır. Bazı durumlarda işaret, simge ve semboller kullanarak öz bir şekilde daha fazlasını, daha geniş bir kitleye aktarma yolunu seçmişlerdir. Bu işaret, simge ve sembolleri belirlerken, tarih boyunca genellikle yakın çevrede bulunan doğal ve beşeri unsurlardan beslendikleri gözlenmektedir (Şenol, 2020). Özetle, insanoğlu yazıdan önce simgeyi bulmuş, suyu, ağacı, yıldızı, bulutu nasıl anlatacağını tasarlamış, sonra da yazıya dönüştürmüştür (Aliağaoğlu ve Çildam, 2016).

Logolar sembollerden oluşur. Sembol, simge ile eş anlamlı olup "duyularla ifade edilemeyen bir şeyi belirten somut nesne veya işaret, alem, remiz, rumuz, timsal" anlamındadır (Türkçe Sözlük, 1998: 1937). Logo, bir şirketin, nesnenin, yayının, kişinin, hizmetin veya bir fikrin belirgin sembolüdür (Center, 2014). Diğer bir ifadeyle logolar, bir kurum, ürün veya hizmeti tanıtmak amaciyla tipografik harflerden oluşturulan sözcüklerin marka veya amblem özelliği taşıyan simgeler şekline dönüşmüş biçimleridir. Logolar, amblemler ve semboller, insanoğlunun geçmişten günümüze kullandığı ve içerisinde bir anlamı barındıran, bu anlamı farklı çevrelerden, yani doğal ortamın özelliklerinden, tarihinden, kültüründen yaşanılan çevrenin gelenek ve göreneklerinden alan imgeler bütünüdür (Uzun ve Özcan, 2014: 273).

Çağdaş anlamda logo kavramının kullanımı 1870'lere dayanıyor. Kayıtlara geçen ilk logo, Bass bira markasının üçgenidir (Center, 2014). Kuşkusuz logo tasarımının bazı ilkeleri vardır. Kurumlarda logo ve bileşenlerini açıklayan kurumsal kimlik kılavuzu yer almalıdır. Logolar zamanla yenilenmelidir. Bu durum çağdaşlık ilkesi olarak ifade edilmektedir. Bütünlük ilkesine göre, simgeler bir arada kullanılmalıdır. Sadelik ilkesine göre, başarılı logoların en önemli ortak özellikleri sadelikleridir. Sadelik ilkesine göre, sade ve basit tasarımlar insanların ilgisini daha çok çeker. Çünkü verilmek istenen mesaj kolay anlaşlıp, hatırlanabilmektedir. Kalabalık tasarımlar insanların dikkatini dağıtır. Dolayısıyla logolar çok sayıda küçük parçadan oluşmamalıdır. Logolarda renk sayısı önemlidir. Bu sayı ikiden fazla olmamalıdır. İyi olmayan logolarda üç renkten fazla renk kullanılır. Uyum ilkesi, renkler arasındaki uyumu ifade etmektedir. Amblemlerde yazı olmalıdır. Kolay okunabilen yazı fontları kullanılmalı, bunlarda büyük ve küçük harflerin birlikte kullanılmaması ve puntoların büyük olması gerekmektedir. Son olarak logolar misyon ve vizyonu da ifade etmelidir (Demirkol, 2019; Cevahir, 2020).

\section{Bulgular}

\section{A. Türkiye'de Değişen (Bazı) Belediye Logoları}

Şehirlerin ortaya çıkışı, siyaset ve devletin ortaya çıkışını sağlamıştır. Şehirler zihniyet ve pratikte farklı görüşlere sahip insanların bir arada yaşadığı yerleşmelerdir. 
Birlikte yaşanılan kendisi gibi olmayanların yaşam alanıdır şehirler. Şehirde ortak iyi arayışı iktidar sahiplerinin iyi kabul ettikleri lehine bir durum ortaya çıkarır (Akın, 2017). Bütün bunlar, yani siyasi nedenler dolayısıyla farklılaşan dünya görüşleri kentsel mekândaki değişim yanında logolardaki sembollerin değişimine de neden olmaktadır. Böylece mekânı politik açıdan kimin kontrol ettiği önem kazanmaktadır. Bu durum en iyi Ankara kentinde ortaya çıkmaktadır. Başlangıçta (1973) Hitit Güneşi kentin logosunda kullanılmıştır. Ancak, "Hitit Güneşi Ankara'yı temsil etmiyor. Hititlerin Ankara'da yaşadığına ilişkin bir belge yok" gerekçesiyle iptal edilmiştir (Özer, 20022003: 95). Bir partiliye göre, "birileri Güneş Kursu’nu amblem olarak alacaksa, o çıktığ1 yere, yani Alacahöyük’e yaraşır" (Akt: Özer, 2002-2003). Bu konuda farklı görüşler vardır. Örneğin Rahmi Kumaş (2014), bu durumu Ankara'da Simge Savaşımı" olarak almış konuyu birkaç kez adli birimlere taşımıştır. Siyasetçi, gazeteci ve eleştirmenlerden gelen başka görüşler de vardır: "Bu şekilde bir yerlere mesaj vermeye çalışıyorlar. $\mathrm{Bu}$ girişim bir çağdış1lıktır", "Yıllardan beri kullanılan Hitit ambleminin değiştirilmesi kent kimliğinin hiçe sayılması anlamındadır" Özer (2002-2003: 102). Sonuç itibariyle, bugün farklı bir logo kullanılmakta, bu logoda muhafazakar kenti minareler sembolize etmektedir (Grafik 1). Yeni yönetime bu logonun değiştirilmesi için baskı vardır. Muhafazakâr gazetelerden biri bu yönde bir öngörüde bulunmuştur.

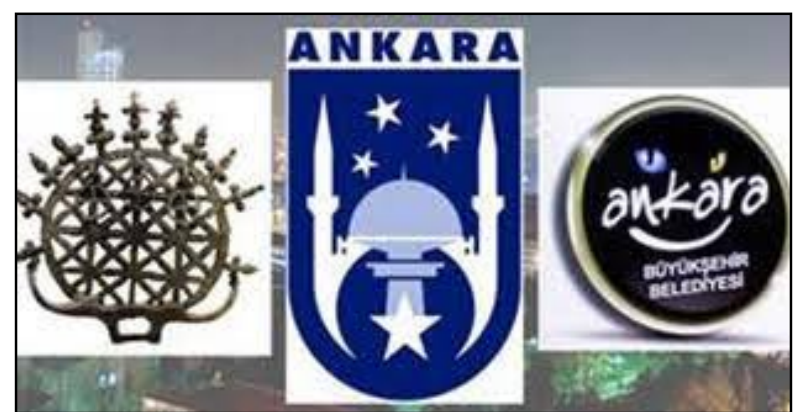

Grafik 1: Ankara Büyükşehir Belediyesi logoları (Akit, 2019).

Yeni Akit Gazetesi yaptığı bir haberde manşet olarak bu durumu ifade etmektedir. "CHP'lilerin Ankara'da ilk icraatı belediye amblemini değiştirmek olacak. Melih Gökçek'ten önce Karayalçın döneminde kullanılan ambleme geri dönülecek" (yeniakit.com.tr). Mersin Büyükşehir Belediyesinde Ak Partiden sonra gelen yeni yönetim logonun değişimi teşebbüsünde bulunmuş fakat olumsuz tepkiler üzerine bu girişimden vazgeçilmiştir (Grafik 2). 


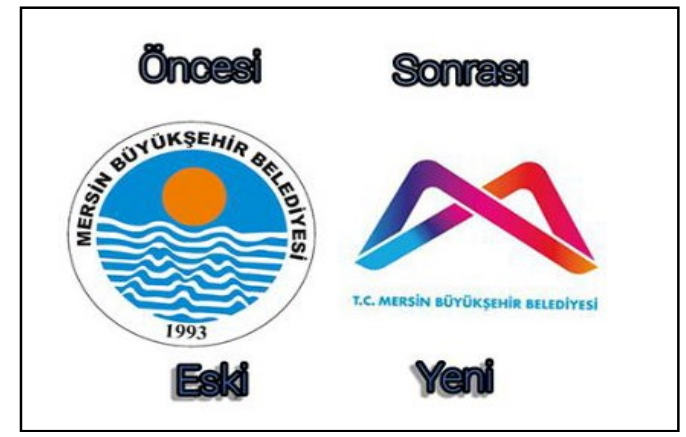

Grafik 2:Mersin Büyükşehir Belediye logoları (Mersin Portal, 2019).

Günümüzde geçmişe ait tarihi değerlerin logolarda ön plana çıktığı görülmektedir. $\mathrm{Bu}$ durum küreselleşmeyle yakından ilgilidir. Bunlardan ilki, nostalji güdüsüdür. Nostalji güdüsü giderek artan ölçüde küresel ve kültürel bir boyut kazanmıştır. Küreselleşmenin hızlanmış nostalji üreten evresinde bulunmaktayız (Robertson, 1999). "Geçmişi koruma güdüsü, insanın kendisini koruması ile ilgili güdüsünün bir parçasıdır. Geçmişi bilmeden gelecekte nereye ulaşabileceğimizi anlamak bu açıdan güçleşmektedir. Geçmiş, bireysel ve kolektif kimliğin zeminini oluşturmakta, geçmişe ait nesneler de kültürel semboller olarak birer anlam kaynağı olmaları açısından önem taşımaktadır. Geçmişten günümüze süregelen süreç, rastlantılara bağlı bir karmaşanın içinden bir süreklilik duygusunun ortaya çıkmasına yol açar. Bu sırada değişim kaçınılmaz bir sonuç olarak karşımıza çıkacaktır. Bu da istikrarlı bir anlam sisteminin hem yeniliklerin hem de bozulmaların üstesinden gelmesini sağlamaktadır" (Hewison, Akt: Harvey, 1997:107, Aliağaoğlu, 2004).

Küreselleşmenin geçmişe ilgiyi artırmasının farklı şekilleri vardır. İnsan hayatı küreselleşmeden etkilendikçe yerel mekânların kültür ve tarihlerinin önemi daha da artmıştır. $\mathrm{Bu}$ önem, yerel değerlerin korunması ve kullanılmasını sağlamıştır (Aliağaoğlu, 2004). Her şeyin sürekli olarak değiştiği bu evrende kaybolmamak için yerel unsurların ön plana çıkarılması gerekmektedir. Kısaca dünyanın tek bir mekân olarak algılanmasını ifade eden küreselleşme, yerele ait olan değerlerin kaybedilmesi endişesini tetiklemekte, kimliksiz şehirlerin ortaya çıkışına neden olmaktadır. Böylece insanlar yerel değerlerine sıkıca bağlanmak istemektedir (Aliağaoğlu ve Çildam, 2015).

Elbistan geçmişini logosuyla korumaktadır(Grafik 3). Eski logoda kullanılan Şar Dağı, Ulu cami ve termik santral yerini yeni logoda Selçuklu simgesi olan sekiz köşeli yıldıza bırakmıştır. $\mathrm{Bu}$ yıldızın her bir köşesi farklı anlamlarla yüklüdür. Bunları merhamet, Rabbine şükretmek, cömertlik, sadakat, sır tutmak, doğruluk, sabretmek ve şefkat şeklinde sıralamak mümkündür. Mühür şeklinde olan logonun merkezinde Bayat Tamgası kentin eski geçmişini ve yüzlerce yıllık medeniyetini sembolize etmektedir. Özetle geçmişe bağlılık ve tarihi vefa kentin önemli özelliği olarak ortaya çıkmaktadır. Aynı durum Pasinler için de geçerlidir Ayrıca sayı biliminde 8 sayısının, cenneti anlatan bir sembol olduğu da söylenmektedir. Dini kaynaklarda İslamiyet'in 8 esasa dayalı olduğu, 8'in cenneti simgelediği belirtilmektedir (Tarlakazan ve Tıngır, 2018). 


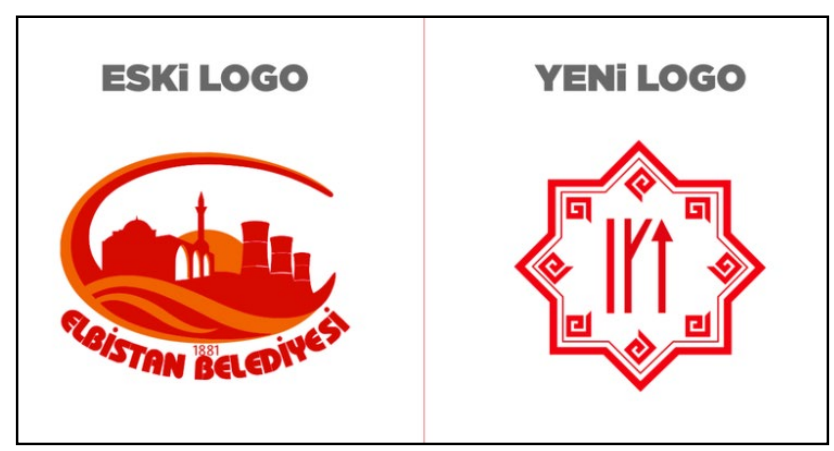

Grafik 3: Elbistan Belediyesinin eski ve yeni logoları (Elbistan Olay, 2019; Şair Dolu Memleket, 2019).

Pasinler Belediyesi de logosunu değiştirmiştir. Eski logoda kale, kaplıca ve başak sembolleri kullanılırken, yeni logoda Selçuklu sekiz köşeli yıldız sembolü kullanılmaktadır (Grafik 4). Bu durum kentin geçmişi ile ilgilidir. 18 Eylül 1049 yılında Pasinler Savaşı yapılmıştır. Selçuklu ve Bizans kuvvetleri arasındaki savaş, Selçukluların zaferi ile sonuçlanmıştır. Pasinler Zaferi Malazgirt öncesi, Selçukluların Anadolu topraklarında kazanmış oldukları büyük başarılardan biridir.

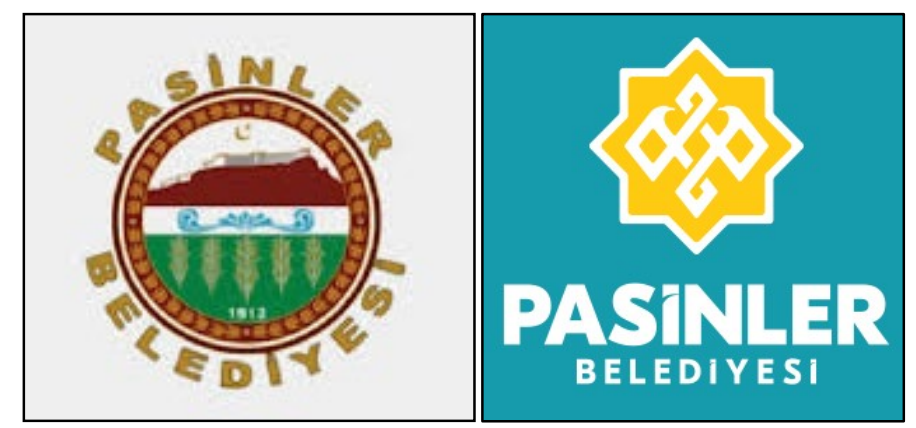

Grafik 4: Pasinler Belediyesi eski ve yeni logoları (Erzurum Belediyesi, 2015; Pasinler Belediyesi, Tarih Yok)

Tarihi değerlere olan bağlılık Karamürsel kentinde farklı şekilde ortaya çıkmaktadır (Grafik 5). Şehir eski logosundaki sembolleri önemsemeyen yeni logoyu kabul etmiş̧ir. Bu durum halkın tepkisin çekmiştir. Eski logo 1902 tarihlidir ve küçük bazı değişiklikler dışında değişmemiş̧tir. Gemi sembolü kıyı lokasyonunu ifade ederken, aynı zamanda yerleşme adının kökenini açıklamaktadır. Karamürsel Alp, İzmit Körfezi çevresinin Osmanlıya katılmasında önemli rol oynar. Gemiler yaparak Osmanlı donanmasının kuruluşuna yardımcı olur. Karamürsel sepeti, Karamürsel Alp'in mezarı ve eski fabrika bacası eski logonun diğer bileşenleridir. Yeni logoda sarı ve mavi renklerle yelken ve 
yol ifade edilmiştir. Aynı özellik Saruhan Belediyesi logosunda da görülmektedir. Şehrin kurucusu olduğu bilinen Saruhan beyi ifade eden sembolün yeni logoda kullanılmaması tepkilere neden olmuştur (Grafik 6).

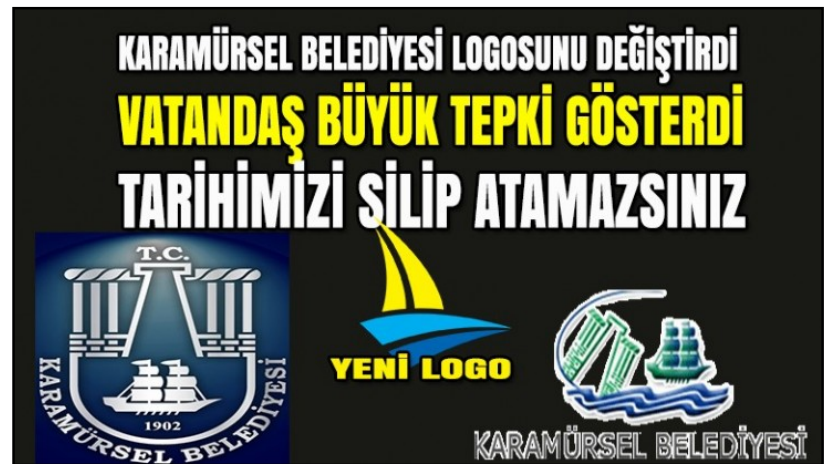

Grafik 5: Karamürsel Belediyesilogoları (Karamürsel TV, 2017).

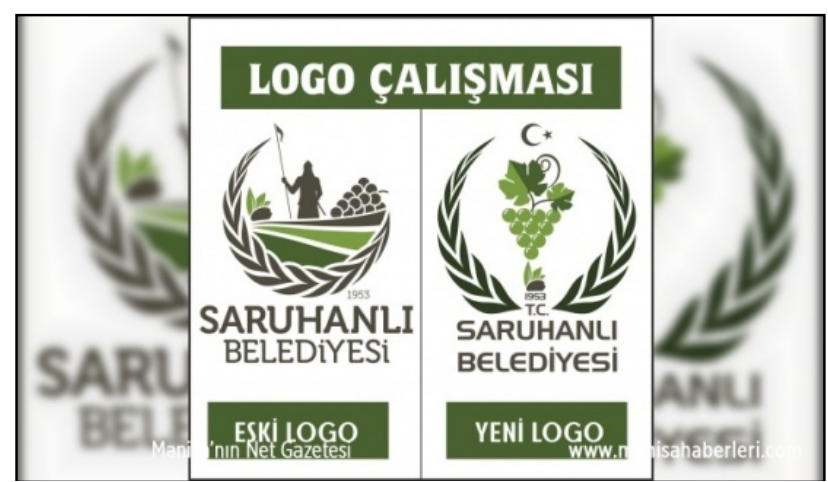

Grafik 6: Saruhan Belediyesi Logoları (Manisa Haberleri, 2019).

Birer yaşayan canlı gibi kabul edilen kentler zamanla kendi yapılarında bir dinamizm ve dönüşüm yaşayabilirler. $\mathrm{Bu}$ durumda demode logolar tekrar canlandırılmalıdır (Aliağaoğlu ve Çildam, 2015).Bazı logolardaki değişim günün şartlarına uydurulması ve sadeleştirmesi kısacası güncelleme ilkesiyle ilgilidir(Grafik 5). Nitekim dünya çapında kullanılan logoların son hallerinde bir sadeleşme olduğu görülmektedir (Aliağaoğlu ve Çildam, 2015). Bu logolar eski logolardaki sembolleri ya korumakta ya da sadeleştirmektedir.

Kocaeli Büyükşehir Belediyesi Logosu değişimin sembollerde değil renklerde yaşandığı logo olmak gibi bir özellik göstermektedir. Eski logoda yer alan semboller korunmuştur. Bunlar Atatürk Heykeli, saat kulesi, sanayi çarkı, kale gibi sembollerdir. Yeni logoda türkuaz rengi benimsenmekte ve yazı fontları daha yumuşak hale getirilmektedir (Grafik 7). 


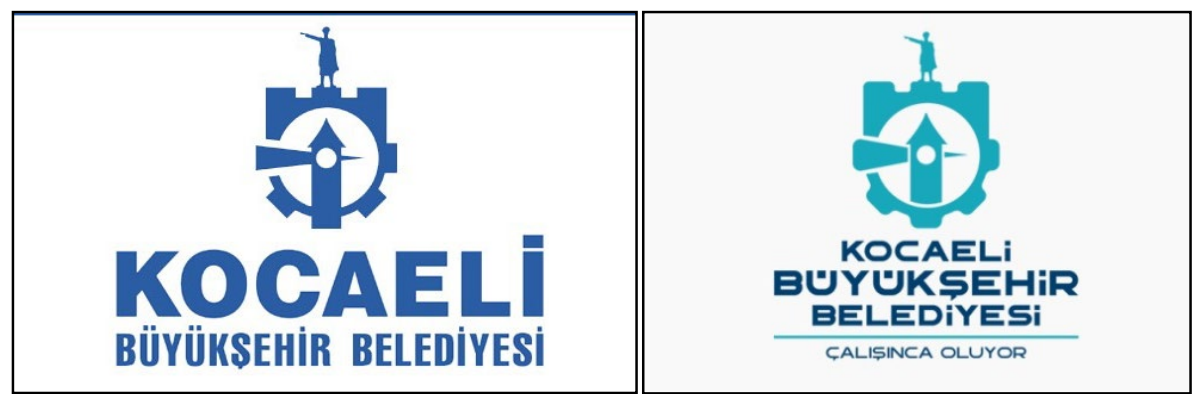

Grafik 7: Kocaeli Büyükşehir Belediyesi eski ve yeni logoları (Birol Vural bir tasarımci.net, 2018).

Niğde Belediyesi, ulusal ve uluslararası alanda yaygınlaşan logo ve ismin bir arada kullanıldığı logoyu seçmiştir. Logoda saat kulesi ön plana çıkmıştır. Seçilen renklerden kahverengi, sağlamlık, güvenilirlik, rahatlık, dayanıklılık, basitlik ve dostluk gibi kavramları sembolize etmektedir. Ayrıca bu renk, toprağı, yani doğumu ve bereketi, başarıya yavaş yavaş ulaşmayı, açık ve dürüst olmayı simgelemektedir. Diğer bir renk ise zümrüt yeşilidir. Bu renk doğayı yaşama umudunu temsil etmektedir (Grafik 8).

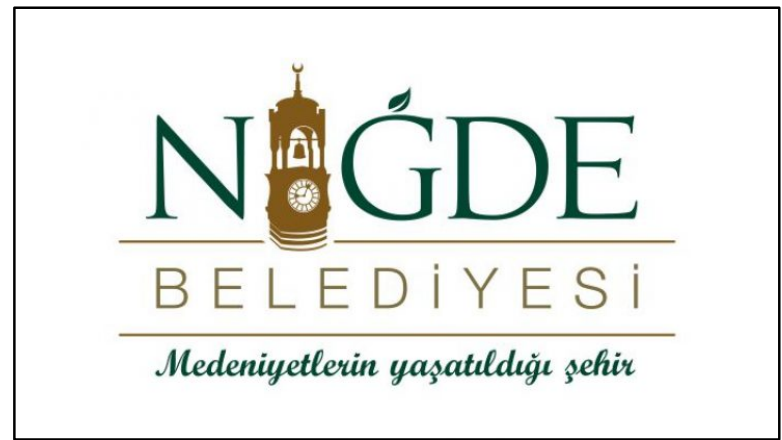

Grafik 8: Niğde Belediyesi Logosu (Niğde Belediyesi, Tarih Yok).

Ekonomik temeldeki değişim logolarda ve sembollerde değişikliğe neden olabilmektedir. Çorlu Belediyesi yeni logosu bu konuda örnek teşkil etmektedir. Değişim Batılı ülkelerde olduğu kentin üretim merkezi olmasından tüketim merkezine dönüşmesi şeklinde değildir. Çorlu tarımsal temelden sanayi temeline doğru yer değiştirmiştir. Buradaki değişimde tarımın öneminin azalmasının etkisi vardır. Devlet tarımdan uzaklaşmış, Keyder ve Yenal'ın ifadesiyle (2013),"bildiğimiz tarımın sonu gelmiştir". Yeşil yapraklar çevre kenti, çevre dostu kenti ifade etmektedir. Sonsuz işareti sonsuz hizmeti nitelerken, çark sanayi faaliyetlerini ifade etmektedir. Sonsuzluk sembolü kısmen Ç (Çorlu) ve B (belediyesi) harflerini de anlatmaktadır. Eski logo çok sayıda sembolden oluşmaktadır. Tarımsal ürünler (başak, ayçiçeği), köprü ve fabrika eski logoda bulunan bazı sembollerdir (Grafik 9). 

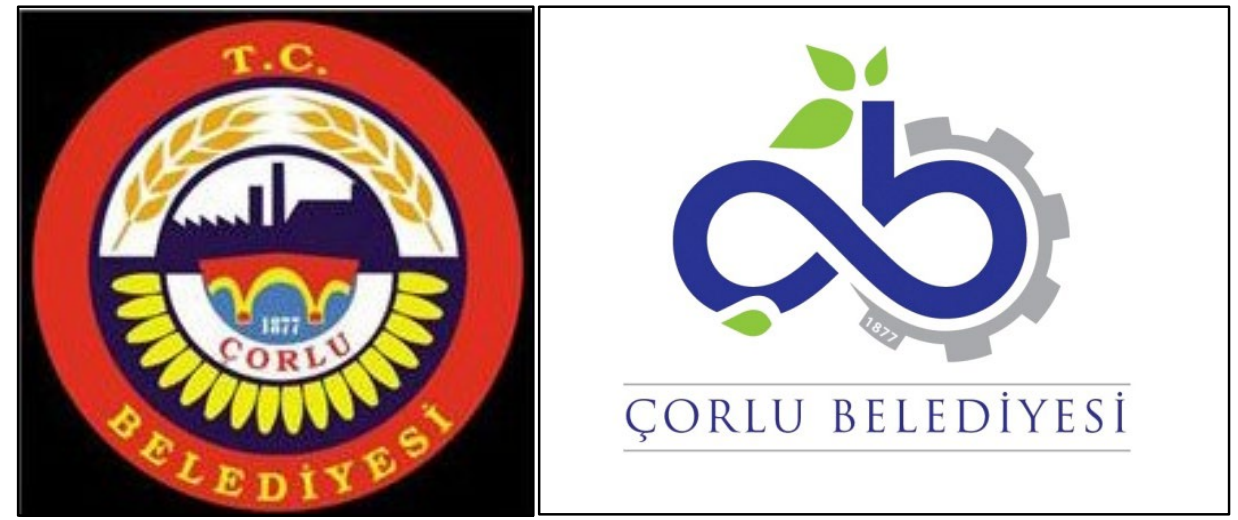

Grafik 9: Çorlu Belediyesi eski ve yeni logoları (Çorluda.com, Tarih Yok; Milliyet Blog, 2009).

Bu konuda bir başka örnek, Buldan kentidir. Küreselleşmenin izlerini kent logosunda görmek mümkündür. Buldan küreselleşme sürecinde altyapı pazarlamasından çok, değer pazarlaması (sosyal, kültürel ve tarihi değerler) yapmaktadır. Kent geçmişte daha çok tarımsal ve sanayi üretimine dayalı ekonomik yapısını yansıtan logosundan vazgeçmiş, logo kentin tarihi ve turistik değerlerini yansıtan sembollerle yeniden tasarlanmıştır (Grafik 10).

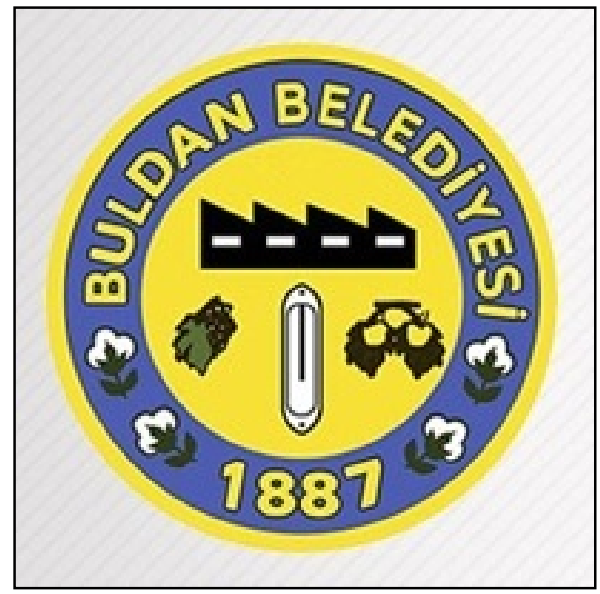




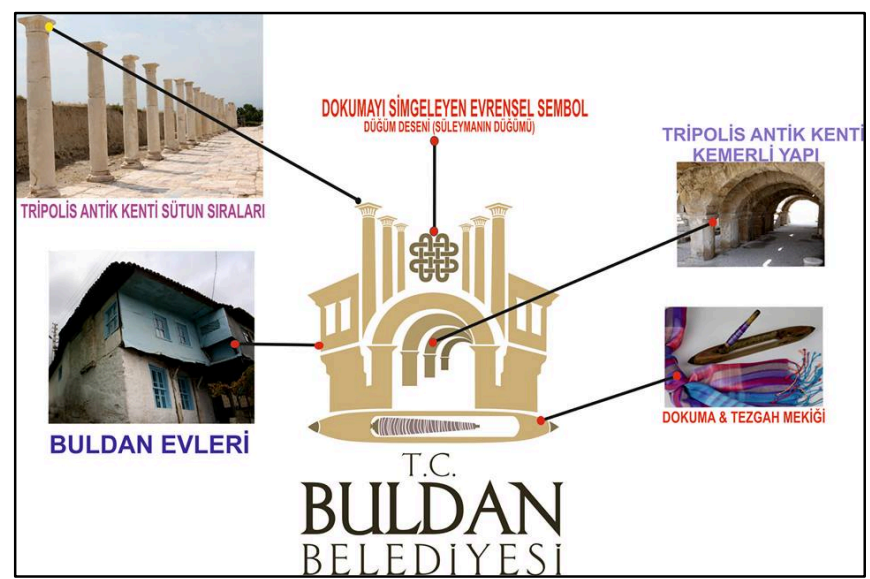

Grafik 10: Buldan Belediyesi Logoları (Denizli Evleri, 2017; Denizli Haber, 2016, Uğur, 2020).

\section{Sonuç}

"Kentler sahip oldukları ekonomik ve toplumsal dizgelerin bir parçası, aynasıdırlar. Genel yapının tüm özelliklerini güzellikleri ve hastalıklarıyla birlikte yansıtırlar (Keleş, 2005: 9). Benzer özellikler logolarda da görülür. Logolar kentseldir. Logolar içinde yaşadığımız kente dair birçok özelliğin taşıyıcısıdırlar. Kentlerin ayırıcı yönü değişime açık olmalarıdır (Şentürk, 2013-14). Başka bir anlatımla değişen ve dönüşen süreçler kentlerde farklı hızlarda değişime neden olur. Bu değişim küreselleşmeyle veya neoliberal politikalarla birlikte son zamanlarda hızlanmıştır. Yeni kapitalizm kentlerde kendi imajına uygun bir kentsel mekân üretmiştir (Şentürk, 2013-14). "Uçucu kimliklerin mekânı olan" (Takış, 2013-14: 8) kentlerdeki bu hızlı değişim logolara da yansımış, onlar değişen koşullara uyum sağlayarak farklı sembollerle ifade edilir olmuşlardır. Yeni semboller eskilerinden tamamen farklıdır veya sembollerde değişim yoktur. Bu çalışmanın konusu Türkiye belediyelerinin bazılarında yaşanan logolardaki değişimdir. Değişimin arka planındaki nedenler küreselleşmeye vurgu yapılarak verilmektedir.

Şenol'a göre (2020), Giresun ilinde logolardaki değişimin altı farklı nedeni vardır. Değişim üzerinde gelişen teknolojinin, okuryazar nüfustaki artışın, tasarım modalarının (akımlarının) büyük etkisi vardır. Ayrıca şehirler büyüdükçe, başlangıçtaki sembollerin önemi azalmaktadır. Hükümet, politika ve yönetim değişimi yeni gelenin çok daha iyi, çok daha farklı fikirleri olduğunu hissettirme isteği veya eski olanın izlerinin silinmesi de logolarda değişime neden olabilmektedir.

Sonuç itibarıyla, hükümet, politika ve yönetim her iki çalışmanın vurguladığı ortak noktadır. Politik görüşte meydana gelen değişim, mekânı fethetmenin bir aracı olarak logolarda değişime götürmektedir. Nitekim Lefebvre'ye göre, "İkamet etme pratiği ve insanların sosyal hayatıyla ilişkisi, mekânın iktidar kapsamına girmesine, dolayısıyla 
politika konusu olmasına sebep olmaktadır (Akt: Birer ve Çalışkan, 2014: 156). Nostalji güdüsü de geçmişe dönmeyi etkilemekte, küreselleşme bu duruma ön ayak olmaktadır.

Küreselleşmenin logolar üzerindeki etkisi Çamlıdere vd. (2006), tarafından da ortaya konulmuştur. Buna göre, büyükşehir belediyeleri ile Kocaeli ili belediyelerinde tarihsel ve geleneksel semboller yanında, mevcut küresel gelişme ve kentsel rekabete de önem verilmiş̧ir. "Küreselleşme süreci; "ekonomik temelli olmakla birlikte siyasal, sosyal, teknolojik ve kültürel özellikleri de olan çok boyutlu bir süreç"tir (Tümtaş ve Ergun, 2016: 135). Logolardaki sadeleşme, yalınlaştırma veya güncelleme de dâhil değişimin esas nedeni neo-liberal ekonomik politikalarıyla ortaya çıkan küreselleşmedir. Küreselleşmeyle birlikte kentler çok hızlı değişmekte ve farklı roller üstlenmektedirler. Kentler bu değişimlerde mekânsal olarak yeniden örgütlenmiş veya mekân savaşlarının alanı olmuş (Bauman, 2012) ve ekonominin aktörü haline gelmişlerdir. Kentlerin varlığının devamı için rekabetçi olmaları gerekmektedir. Böylece kentler konumlarına ve sahip oldukları ekonomik, kültürel ve diğer alt yapı varlıklarına göre küresel kent hiyerarşisinde yer kapmaya çalışmaktadır. Zaten rekabet edebilirlik, "kentlerin/bölgelerin işgücü ve yatırım gibi mobil üretim faktörlerini çekme ve bölgede tutma becerisi olduğu yönündedir" (Eroğlu ve Yalçın, 2014: 22). Rekabetçi olmanın başka bir yolu markalaşmaktır. Kentler, ürünler gibi markalaşmaktadır. Markalaşma iyi olanı ifade etmektedir. Başka bir anlatımla, kentlerin markalaşmak, tercih nedeni veya çekici olmak için ekonomik alt yapıların hazırlanması ve diğer nedenler yanında logolarını da güncellemesi gereklidir. Diğer yandan, yerelleşme önemli hale gelmiş, küreselleşmeyle birlikte ortaya çıkan kaos ortamı kentlerin yerel tarihi ve kültürel değerlere sahip çıkmasını gerekli kılmıştır.

Logoların tasarımında keyfi davranılmamalı, coğrafik özelliklere vurgu yapılmalıdır. Logolardaki sembollerin tespiti sadece tek bir bilimin katkısıyla yapılmamalı, konuyla ilgili disiplinler tarafindan alınacak ortak kararlar sonucu tespit edilmelidir. Logolardaki değişim çağdaşlık ilkesinin bir sonucudur. Kamuoyunun bu konuda bilinçlendirilmesi gerekmektedir. Logoları açıklayan kurumsal kimlik kılavuzları hazırlanmalıdır. Burada eski ve yeni logo birlikte verilmeli değişiklik yapılmışsa nedenleri de açıklanmalıdır.

Bu çalışmada belediye logoları ele alınmaktadır. Ancak değişen bütün logoları ortaya çıkarmak iddiasında değildir. Değişimin nedenleri olarak dört faktör belirlenmiştir. $\mathrm{Bu}$ faktörlere göre örnekler seçilmiştir. Ancak Şenol'un (2020) tespitleriyle bu sayı artmaktadır. Logolardaki değişimin tek bir açıklaması da yoktur. Çok nedenli açıklamalar da değişimi ortaya koyabilir. Ayrıca başka nedenlerin çıkması da söz konusu olabilir. Gerek bu nedenlerin araştırılması gerekse Türkiye çapında valilik logolarında ve diğer kurumsal logolarda değişimin yaşanıp yaşanmadığı, yaşanmışsa nasıl yaşandığı ve nedenleri başka bir coğrafi içerik çalışmanın konusu olabilecek potansiyele sahiptir. 


\section{Kaynaklar}

Akın, M.H. (2017). “Şehir Siyaset İlişkisinin Varoluş Diyalektiği”. Düşünen Şehir, 1, 74-79.

Akit. (2Nisan2019).CHP'lilerin Ankara'da ilk işi logoyu değiştirmek! https:/www.yeniakit.com.tr/haber/chplilerin-ankarada-ilk-isi-logoyu-degistirmek689326.html

Aliağaoğlu, A. (2007). "Lakap ve Logolarda Türkiye Şehirleri: Anlamların Coğrafyası”. Doğu Coğrafya Dergisi, 12(17): 263-290.

Aliağaoğlu, A. Çildam, S. Y. (2016). Belediye Logoları ve Kent Kimliği: Balıkesir Örneği. Balıkesir 2. Kent Sempozyumu, 20-22 Kasım 2015, (ss. 617-636), Balıkesir: Balıkesir Akademik Odalar Birliği.

Aliağaoğlu, A. ve Uğur A. (2018). "Logolarda Erzurum Kent Kimliği: Yorumlayıc1 Anlamaya Yönelik Bir Çalışma”. Atatürk Üniversitesi Sosyal Bilimler Enstitüsü Dergisi, 22(4), 2357-2379.

Aslanoğlu, R. A. (1998). Kent, Kimlik, Küreselleşme. Asa.

Bauman, Z. (2012). Küreselleşme Toplumsal Sonuçları. Ayrıntı.

Bilirdönmez, T. ve Şahin, C. (2019). Doğu Karadeniz Bölgesi Şehirlerinin Belediye Logolarındaki Tanıtıcı Sembollerin Analizi. Uluslararası Sosyal ve Beşeri Bilimler Dergisi, 2 (2), 38-47.

Birer, E. ve Çalışkan, G.A. (2014). "Mimarlık Eğitiminde Konuşul-a-mayanlar: Politika ve Siyaset". Idealkent, 13, 152-170.

Birol Vural birtasarımcı.net. (2018, Eylül 13). Kocaeli Belediyesi Logosunu Değiştirdi. https:/birtasarimci.net/grafik-tasarim/kocaeli-belediyesi-logosunu-degistirdi/

Braun, E. (2008). City Marketing: Towards an Integrated Approach. Erasmus Research Institute of Management (ERIM), ERIM PhD Series in Research and Management, 142.

Büyükçanga, M. (2003). "Konya Merkez İlçe belediye amblemleri”. Caner Arabacı (Ed.), Konya Kitabı, IV (373-378) içinde. Bahçıvanlar Basım San. A.Ş.

Büyükçanga, M. (2004). "Ilgın, Kadınhanı, Sarayönü, Karapınar, Hadim İlçelerinin Belediye Amblemleri”. Caner Arabacı (Ed.), Konya Kitabı, IV (403-406) içinde. Damla Ofset.

Cevahir, M. A. (2010). Kimlik Göstergesi Olan Logoların; İçerik Analizi, Vizyon, Misyon Açısından İncelenmesi, İstanbul Belediyeleri Örneği (Yüksek Lisans Tezi). İstanbul: Üsküdar Üniversitesi Sosyal Bilimler Enstitüsü.

Çamdereli M., Varlı M., Varlı Z. ve Gürer M. (2006). "Kentsel kimlik göstergesi olarak kent logoları”. II. Ulusal Halkla İlişkiler Sempozyumu (21. Yüzyılda Halkla 
İlişkilerde Yeni Yönelimler, Sorunlar ve Çözümler), 27-28 Nisan 2006,(235-280), Kocaeli: Kocaeli Üniversitesi.

Çamdereli, M. (2004). Bir Kamusal İletişim Aracı Olarak İBB Logosu Nasıl Okunmalıdır? İçinde Metin Işsk. Medyada Yeni Yaklaşımlar, 239-253. Eğitim Kitabevi Yayınları.

Çeliker, M. ve Tokoğlu, A. A. (2017). "Marka kent oluşturulmasında grafik tasarımın rolü ve Gaziantep Örneği”. Süleyman Demirel Üniversitesi Güzel Sanatlar Fakültesi Sanat Dergisi (SDÜ ART-E), 10(19), 136-159.

Çorluda.com. (Tarih Y̧orlu Yok). Yeni Logosu. http://www.corluda.com/corlu_belediyesi_yeni_logosu.asp

Demir, H. (2013). “Mersin'de kentsel kimlik göstergeleri olarak kullanılan logolara ilişkin bir değerlendirme". Sanat Dergisi, 22, 115-122.

Demirci, A. (2014). "Literatür Taraması". Yılmaz Arı ve İlhan Kaya (Ed.), Coğrafya Araştırma Yöntemleri (ss. 73-106)içinde. Balıkesir: Coğrafyacılar Derneği.

Demirkol, U. (2019). Türkiye Cumhuriyeti Valilik Logo ve Amblemlerin Tasarım Elemanları, Tasarım İlkeleri ve İçerik Açısından İncelenmesi (Yüksek Lisans Tezi), Giresun Üniversitesi Sosyal Bilimler Enstitüsü.

Denizli Evleri. (16Mayıs2017). Buldan Belediyesi Yeni Logonun Anlamı Nedir? http://www.denizlievleri.com/detay/288/buldan-belediyesi-yeni-logonun-anlaminedir?

Denizli Haber. (19 Şubat 2016). Buldan Belediyesi'nden Terör Protestosu. https://www.denizlihaber.com/denizli/buldan/buldan-belediyesinden-terorprotestosu.

Elbistan Olay. (17Mayıs2019). Elbistan Belediyesi Logosunu Değiştirdi. https://www.elbistanolay.com/haber/2551471/elbistan-belediyesi-logosunudegistirdi.

Eroğlu, O. ve Yalçın, A. (2014). "Yeni Bir Rekabet Formu Olan Kent Rekabetçiliğine Yönelik Literatür Taraması". Çankırı Karatekin Üniversitesi İktisadi ve İdari Bilimler Fakültesi Dergisi, 4(1), 19-42.

Erzurum Belediyesi. (17Ağustos2015). İlçe Belediyeleri. https://www.erzurum.bel.tr/IcerikDetay-ilce_belediyeleri/11/I.html.

Fettahlığlu, S., Yıldız, A. ve Göksu, N. (2017). "Kahramanmaraş Halkının Şehir Pazarlaması Sürecinde Algısının Ölçülmesi ve Logo Geliştirilmesine Yönelik Bir Çalışma”. Journal of Social and Humanites Sciences Research, 4(15), 1924-1936. https://doi.org/10.26450/jshsr.305.

Giritlioğlu, İ. ve Avcıkurt, C. (2010). "SSehirlerin Turistik Bir Ürün Olarak Pazarlaması, Örnek Şehirler ve Türkiye'deki Şehirler Üzerine Örnekler (Derlemeden Oluşmuş Bir Uygulama)". Adiyaman Üniversitesi Sosyal Bilimler Enstitüsü Dergisi, 3(4), 74-89. 
Görgülü, Y. (2019). "Kentlerin Markalaşması Sürecinde Logoların Kimlik İnşası: Antalya Örneği Göstergebilimsel Bir Çözümleme”. Elektronik Cumhuriyet İletişim Dergisi, 1(3): 65-83.

Harvey, D. (1997).Postmodernliğin Durumu. Metis.

Hugo, V. (1996). Kentin Felsefesi. Cogito, Kent ve Kültürü, 8, 63-70.

Karaalan, Ö.K. (1998). Türkiye İller Amblemi (Yüksek Lisans Tezi), Marmara Üniversitesi Sosyal Bilimler Enstitüsü.

Karamürsel TV. (3Mayıs 2017). Karamürsel Belediyesinin Yeni Logosu Beğenilmedi. https://karamursel.tv/karamursel-belediyesinin-yeni-logosu-begenilmedi/4534.

Kavaratzis, M. \& Hatch, J. M. (2013). "The Dynamics of Place Brands: An IdentityBased Approach to Place Branding Theory" (Yer Markalarının Dinamikleri: Yer Markalaşma Teorisine Kimlik Temelli Bir Yaklaşım). Marketing Theory, 13(1), 6986. https://doi.org/10.1177/1470593112467268.

Kavuran, T. ve Çetinkaya, A. (2015). Elazı̆̆ İli ve İlçe Belediyelerinin Logo ve Amblemlerinin Görseli. Fırat Üniversitesi Kurumsal Açık Arşiv. https://acikerisim.firat.edu.tr/xmlui/handle/11508/8448?locale-attribute=tr.

Kaya, İ. (2014). "Coğrafi Düşüncenin Değişimi ve Paradigmalar", Yılmaz Arı ve İlhan Kaya (Ed.), Coğrafya Araştırma Yöntemleri (ss.19-50) içinde. Balıkesir: Coğrafyacılar Derneği.

Kaypak, Ş. (2013). "Küreselleşme Sürecinde Kentlerin Markalaşması ve Marka Kentler". C. Ü. İktisadi ve İdari Bilimler Dergisi, 14(1), 335-355.

Keleş, R. (2005). “Kent ve Kültür Üzerine”. Mülkiye Dergisi, 29(246), 9-18.

Keyder, Ç. ve Yenal, Z. (2013). Bildiğimiz Tarımın Sonu, Küresel İktidar ve Köylülük. İletişim.

Kızıltaş, S. (2017). "Mekân Pazarlama Yaklaşımıyla Ülke ve Şehir Logolarının Analizi”. IMÜ Sanat, Tasarım ve Mimarlk Fakültesi Dergisi, 3(2): 214-229.

Köşker, H.,Albuz, N. ve Ercan F., (2019). “Türkiye'de Turistik Talebin En Fazla Olduğu 10 Kentin Marka Kimlikleri Üzerine Bir Değerlendirme”. Gaziantep University Journal of Social Sciences, 18(1), 348-365.

Kumaş, R. (2014). Ankara'da Simge Savaşımı, ODTÜ Mimarlık Fakültesi.

Kurtoğlu, R. (2017). "Şehir pazarlaması ve markalaşması kapsamında Yozgat İlinin potansiyelinin değerlendirilmesi ve öneriler”. Turkish Journal of Marketing, 2(1), 120.

Lee, S.,Rodriquez, L. \& Sar, S. (2012). “The Influence of Logo Design on Country Image and WillIingness to Visit: A Study of Country Logos for Tourism"(Logo Tasarımının Ülke İmajı ve Ziyaret Etme İsteği Üzerindeki Etkisi: Turizm için Ülke Logolarının İncelenmesi).Public Relation Review, 38, 584-591. 
Manisa Haberleri. (6Kasım2019). Belediyenin Değişen Logosu İlçede Tartışmaya Neden Oldu. https://www.manisahaberleri.com/saruhanli/belediyenin-degisenlogosu-ilcede-tartismaya-neden-oldu-h105888.html.

Mersin Portal. (12 Kasım2019). Mersin Büyükşehir Belediyesi'nin Logosu Alıntı mı? https://www.mersinportal.com/ozel-haber/mersin-buyuksehir-belediyesinin-logosualinti-mi-h52897.html.

Milliyet Blog. (22 Aralık 2009). Çorlu'da Logo Yarışması. http://blog.milliyet.com.tr/corlu-da-logo-yarismasi/Blog/?BlogNo=220388.

Niğde Belediyesi. (Tarih Yok). Akaryakıt Ürün Alım İşi. https://www.nigde.bel.tr/tender-detail/12/290/akaryakit-urunleri-alim-isi.aspx.

Ocak, E. (1996). "Kentin Değişen Anlamı”. Birikim, 86-87, 32-41.

Özer, A. (2002-2003). "Türkiye Cumhuriyeti'nin Başkenti Ankara için Düşünülen Amblem ve Tartışmalar. Anadolu Üniversitesi”. Sosyal Bilimler Dergisi, 2(1), 95108.

Özsöz, M. F. (2018). "Şehir Pazarlamasında Bir Marka Şehir Olarak Eskişehir'in İncelenmesi”. USOBED Uluslararası Batı Karadeniz Sosyal ve Beşeri Bilimler Dergisi, 2(1), 12-34.

Özyurt, C. (2005). Küreselleşme Sürecinde Kimlik ve Farklılaşma. Açılım Kitap.

Pasinler Belediyesi. (Tarih Yok). https://www.pasinler.bel.tr/

Richards, G., (2004).“The Impact of Cultural Events on City Image: Rotterdam, Cultural Capital of Europe 2001" (Kültürel etkinliklerin şehir imajına etkisi: Rotterdam, Avrupa'nın Kültür Başkenti 2001). Urban Studies, 41(10), 1931- 1951.

Ritzer, G. (2010). Küresel Dünya. Ayrıntı.

Robertson, R. (1999). Küreselleşme, Toplum Kuramı ve Küresel Kültür. Bilim ve Sanat.

Short, J.R., Benton, L.M., Luce, W.B. \& Walton, J. (1993). "Reconstructing the Image of an Industrial City" (Bir Sanayi Kentinin İmajını Yeniden İnşa Etmek).Annals of Association of American Geographers, 83(2), 207-224.

Smith, A., (2005)."Reimaging The City The Volue of Sport Initiatives" (Şehrin Spor Girişimlerinin Değerini Yeniden Gözden Geçirmek). Annals of Tourism Research, $32(1), 217-236$.

Şair Dolu Memleket. (5Mayıs 2019). Elbistan Belediyesi Logosunu Değişti. https://sairdolumemleket.com/yerel/46haber/elbistan-belediyesi-logosunudegisti/3004.

Şentürk, Ü. (2014). "Mekân Sadece Mekân Değildir: Kentsel-Mekânın Yeni Tezahürleri”. Doğu Batı Şehir Yazıları I, 67, 85-106.

Takış, T. (2014). Bir Şehir Farklı Tür İnsanlardan Oluşur. Benzer İnsanlar Bir Şehir Meydana Getiremezler. Doğu Batı Şehir Yazıları I, 67, 7-8. 
Talas, M. ve Kaya. Y. (2007). Küreselleşmenin Kültürel Sonuçları. TÜBAR XXII, 149162.

Tarlakazan, E.B. ve Tıngır, M. (2018). "Selçuklu İzleri Taşıyan Kimi Belediye Amblemlerindeki Sembollerin Tarihi, Kültür ve Tasarım Açısından İncelemesi”. Erzincan Üniversitesi Sosyal Bilimler Enstitüsü Dergisi, 9(1), 111-128.

Tomlinson, J. (2013). Küreselleşme ve Kültür. Ayrıntı.

Tuan Y. (1976). "Hümanistik Coğrafya". Annals of Association of American Geographers, 66(2), 277-292.

Tümertekin, E. ve Özgüç, N. (2016). "Ekonomik Coğrafya Küreselleşme ve Kalkınma". Çantay Yayınevi.

Tümertekin, E. ve Özgüç, N. (2017). Beşeri Coğrafya İnsan Kültür Mekân. Çantay Yayınevi.

Tümtaş, S. ve Ergun, C. (2016). “Küreselleşme ve Kentlere Etkileri”. SDÜ Fen-Edebiyat Fakültesi Sosyal Bilimler Dergisi, 37, 135-150.

Türkan, O. (2018). "Evaluation of Spatial Symbol on Municipal Logos: Sample of Çankırı Province", Gülçin Taşkıran ve Ercan Geçkin(Ed.), Current Debates in Gender \& Cultural Studies (ss. 153-166)içinde. IJOPEC Publication.

Uğur, A. ve Aliağaoğlu, A. (2018). Şehir Coğrafyası. Nobel Yayınevi.

Uğur, A. (2020). "Belediye Logoları ve Şehir Kimliği: Denizli İli Örneği”, Mithat Aydın, Süleyman İnan (Ed.),Dr. Kemal Daşçığlu'na Vefa Kitabı (ss. 895-918) içinde. Pegem Akademi.

Uzun, M. ve Özcan, S. (2014). "Belediye Logolarındaki Coğrafi Sembollerin Analizi: Kocaeli Örneği”. Uluslararast Sosyal Araş̧tırmalar Dergisi, 7(32), 272-288.

Wahyurini, O.D. (2012). "The Significance of City Logo in City Branding Strategy. Recent Researches in Engineering Mechanics" (Şehir markalaşma stratejisinde şehir logosunun önemi. Mühendislik mekaniğinde son araştırmalar). Urban \& Naval Transportation and Tourism, 79-84.

Yenipınar, U. ve Yıldırım, O. (2016). "Destinasyon Markalaşmasında Yerel Simgelerin Logo ve Amblemlerde Kullanılması: Muğla Araştırması". Seyahat ve Otel Isşletmeciliği Dergisi, 13(1), 28-46.

Zeren, H. E. (2011). "Stratejik Kent Yönetimi ve Kent Markası Oluşturma Süreci”. Kahramanmaraş Sütçü İmam Üniversitesi İktisadi ve İdari Bilimler Fakültesi Dergisi, 1(2), 175-200. 